\title{
Meeting Report on "Hodgkin lymphoma: Case presentation and treatment outcome in Tenri Hospital"
}

\author{
Hitoshi Ohno* \\ Department of Hematology, Tenri Hospital \\ Received 2013/7/26; accepted 2013/8/20; released online 2013/12/25
}

On February 2, 2013, a mini-symposium entitled: "Hodgkin Lymphoma: Case Presentation and Treatment Outcome in Tenri Hospital" was held in Nara Royal Hotel. The key feature of this symposium was that it was specifically aimed at providing a platform for resident physicians of Tenri Hospital to present their knowledge and understanding of Hodgkin lymphoma obtained through the management of their own patients with this particular disease. The symposium attracted clinical hematologists, radiologists, and pathologists working in Nara Prefecture involved in the diagnosis and treatment of hematological tumors. In this meeting report, we briefly present a biography of Dr. Thomas Hodgkin, who first described the disease bearing his name, 180 years ago. Next, we highlight some of the most significant findings reported by the young and talented physicians-in-training of Tenri Hospital.

Keywords: Hodgkin lymphoma, Dr. Thomas Hodgkin, resident physician

\section{BIOGRAPHY OF DR. THOMAS HODGKIN}

In 1826, Dr. Thomas Hodgkin (Figure 1), at the age of 28 , was appointed as the first lecturer of morbid anatomy and museum curator at the newly established Guy's Hospital Medical School in London. During the next 12 years at Guy's, Dr. Hodgkin made a number of major contributions (Table 1). A paper entitled: "On Some Morbid Appearances of the Absorbent Glands and Spleen" was read on January 10 and 24, 1832, before the Medical and Chirurgical Society of London and was published in the seventeenth volume of Medico-Chirurgical Transactions, and its abstract appeared in the Boston Medical and Surgical Journal on March 28, 1832. Dr. Hodgkin, in this

*Correspondence to: Hitoshi Ohno, MD, PhD

Department of Hematology, Tenri Hospital

200 Mishima, Tenri, Nara 632-8552, Japan

e-mail: hohno@tenriyorozu.jp paper, described clinical and postmortem findings of a total of 7 cases, characterized by marked enlargement of the lymph nodes ("absorbent glands"), equaling the size of a "pullet's egg", and the spleen; the cut surface of the latter organ was found to contain multiple nodules ("tubercles", "small, white, nearly opaque spots", or "specks"). As he was unable to identify significant pathological conditions that were known to cause lymphadenopathy at that time (i.e., carcinoma, inflammation, tuberculosis, and syphilis), he correctly concluded that the disease does not represent a secondary response to an obscure inflammatory process but rather primarily develops within the lymph nodes themselves ("primary affection" or "idiopathic interstitial enlargement"), and that the spleen, which had been considered to be an organ to store the blood, has a connection with the lymph nodes and is, in fact, a lymphatic organ. It is notable that Dr. Hodgkin 
confessed at the end of the paper that he had no help to offer patients for the treatment of the disease, "either curative or palliative". We are currently able to view this article published in 1832 on the internet, as well as the watercolors of the pathological features that were displayed before the Medical and Chirurgical Society of London while the paper was being read. ${ }^{1}$

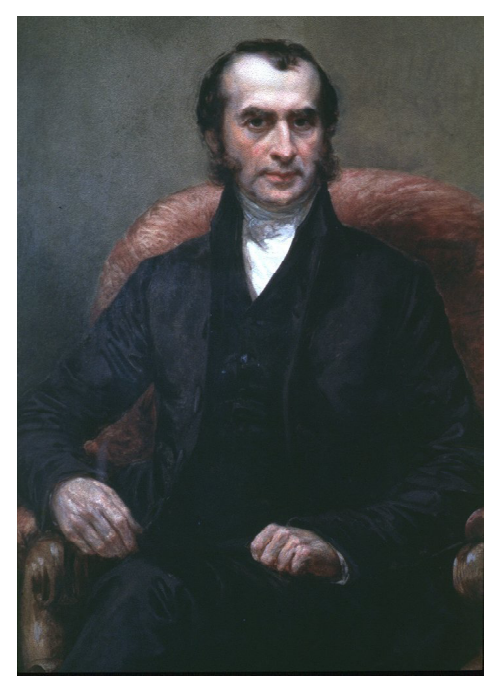

Figure 1. Thomas Hodgkin (1798-1867). Reproduced courtesy of the Gordon Museum of Pathology, King's College London.
Unfortunately, Dr. Hodgkin resigned from Guy's Hospital in 1837 and his academic medical career concluded at that time. He devoted the latter half of his life to helping and educating underprivileged and oppressed people and children. ${ }^{2}$ His 1841 publication (Table 1) summarized lectures to the public on ways to promote and preserve individual health. He also traveled with Sir Moses Montefiore, who was a successful financier and philanthropist, to Morocco. His interest in ethnology, geography, and anthropology could be noted in his 1866 publication (Table 1), where three color lithographs of landscapes in Morocco from drawings by Dr. Hodgkin during the trip were presented. ${ }^{2}$ He finally visited Palestine for philanthropic purposes, and died of dysentery-like disease there in 1866.

Although Dr. Hodgkin's paper of 1832, among the rest, attracted no attention at the time of publication, Sir Samuel Wilks, who was a well-known physician at Guy's Hospital, rediscovered the paper and proposed the eponym of "Hodgkin Disease" for this particular condition in his paper on Guy's Hospital Reports; the paper was entitled: "Cases of Enlargement of the Lymphatic Glands and

Table 1. Publications of Dr. Thomas Hodgkin archived in Google Books

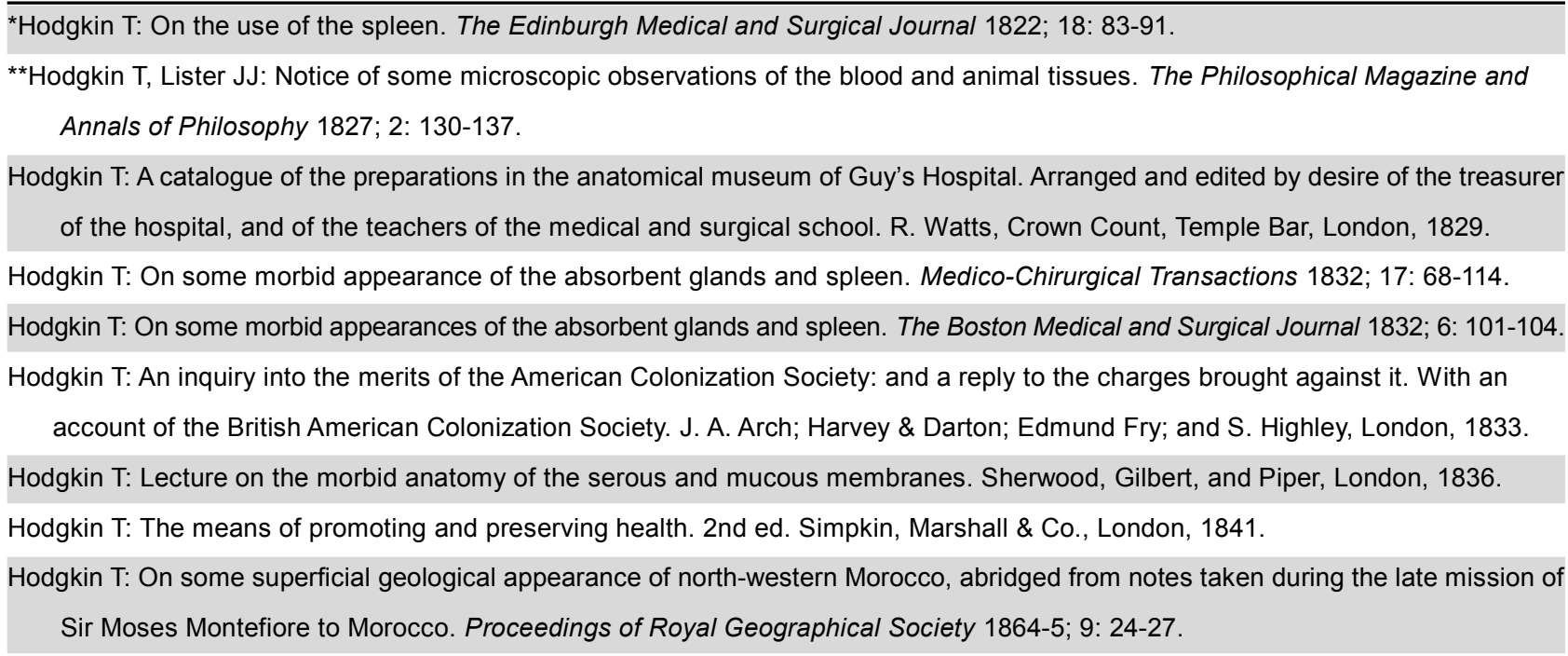

Hodgkin T: Narrative of a journey to Morocco, in 1863 and 1864, with geological annotations. T Cautley Newby, London, 1866.

${ }^{*}$ Hodgkin received his medical degree from Edinburgh in 1823 following this study.

**Using a microscope, Hodgkin and Lister discovered the biconcave shape of human erythrocytes and striations in skeletal muscle. 
Spleen, (or Hodgkin's Disease) with Remarks", which was published one year before the death of Dr. Hodgkin. ${ }^{3} \mathrm{He}$ determined that the disease initially develops in the lymph nodes, spreads late to the spleen along the lymphatic system, and finally infiltrates other visceral organs. Sir Wilks acknowledged that "Dr. Hodgkin was the first to call attention to this peculiar form of disease." 3 Dr. Hodgkin together with Richard Bright and Thomas Addison are currently praised as the great triumvirate of Guy's.

\section{REPORT ON THE MINI-SYMPOSIUM}

The symposium was held on February 2, 2013, at Nara Royal Hotel. Speakers were young and talented resident physicians of Tenri Hospital. They presented their knowledge and understanding of Hodgkin lymphoma (HL) obtained through daily clinical practice in the management of their own patients with this particular disease. Participants included clinical hematologists, radiologists, and pathologists working in Nara Prefecture involved in the diagnosis and treatment of hematological tumors.

Yoshimasa Kamoda (senior resident, Department of Hematology, Tenri Hospital) first presented the historical picture of histopathology drawn by Dorothy Reed in 1902, showing the characteristic Reed-Sternberg (RS) giant cells. Next, he overviewed HL with regard to the classification, clinical staging, risk factors, and treatments. Currently, HL is divided into two major subgroups, classical HL (CHL) and nodular lymphocyte-predominant HL, and the former subgroup is further divided into four subtypes of Rye: nodular sclerosis (NS), mixed cellularity (MS), lymphocyte-rich (LR), and lymphocyte-depleted. The standard staging system of HL is the Ann Arbor scheme modified at the Cotswold meeting, and the International Prognostic Score, consisting of 7 prognostic factors, is the most widely used risk stratification index for HL. Although the ABVD combination is the standard chemotherapy regimen, the number of cycles required and combination with radiotherapy are still under debate. Kamoda chaired the following three presentations.

Tsutomu Wada (junior resident, Tenri Hospital) pre- sented a case of the NS subtype of CHL. The lymphoma developed in an older man and carried the Epstein-Barr virus (EBV). In industrialized countries including Japan, CHL has a bimodal age distribution curve: there is one major peak in young adults (approximate age 20 years) and another minor peak in older adults (approximate age 65 years). The rate of EBV positivity among HL varies depending on geography, patient ethnicity, histologic subtype, and age. Wada suggested that the lymphoma of this case may not be identical to NSCHL that develops in younger people, in which EBV is infrequently detected. Fortunately, the interim ${ }^{18} \mathrm{~F}$-fluorodeoxyglucose (FDG) positron emission tomography (PET) performed after two cycles of ABVD showed complete resolution of the disease, predicting the favorable treatment outcome of the patient.

Shunsuke Nishimura (junior resident, Tenri Hospital) presented a case of the MC subtype of CHL. It was notable that the lymphoma infiltrated the bone marrow (BM) at initial presentation. Nishimura showed multinucleated RS cells on a BM smear slide stained by May-Giemsa, which were surrounded by macrophages ingesting blood cells. A biopsy specimen of the BM demonstrated polymorphic cellular infiltrates including CD30-positive RS cells. The B-cell origin of the lymphoma cells was confirmed by the expression of CD20 and amplification of a single fragment of the complementarity-determining region of the immunoglobulin heavy chain gene. In general, diffuse BM uptake in ${ }^{18}$ F-FDG PET at the initial staging of HL does not indicate BM infiltration of HL, but simply reflects an inflammatory condition associated with HL in most cases. Although there is a report that routine $\mathrm{BM}$ biopsy has little or no therapeutic value for ${ }^{18} \mathrm{~F}-\mathrm{FDG}$ PET-staged treatment-naïve patients with HL, Nishimura suggested that the BM test is still mandatory to detect BM disease and, at present, ${ }^{18}$ F-FDG PET cannot be a substitute for BM aspiration/biopsy.

Kiyotaka Izumi (junior resident, Tenri Hospital) reported the clinical outcome of HL patients diagnosed and treated in Tenri Hospital. Izumi reviewed the medical 
records of a total of 37 patients, including 24 with NS, 6 MC, one LR, and 6 subtype-undetermined. Thirty-six patients were treated with chemotherapy, most frequently with $\mathrm{ABVd} / \mathrm{ABVD}$, and $24(64.9 \%)$ patients achieved a complete/partial response. The survival analysis of all patients revealed that the five-year overall survival (5yOS) was $73.0 \%$ and the progression-free survival (5yPFS) was $72.0 \%$, being inferior to those of the phase II study of ABVd, conducted by the Japan Clinical Oncology Group (JCOG). Nevertheless, for 27 patients $<70$ years old, the survival rates (5yOS, 82.7\%; 5yPFS, 81.7\%) were comparable to those of the JCOG study (5yOS, 91.3\%; 5yPFS, $78.4 \%$ ). Izumi suggested that we have to develop effective treatments that are applicable to elderly patients.

\section{CONCLUDING REMARKS}

The aim of this symposium was to provide a platform for resident physicians with an interest in hematology/ oncology to present their findings obtained through daily clinical practice. The exciting discussions with senior physicians who participated in the symposium clearly in- dicated that the aim had been fulfilled. The feedback from the participants was very positive, and they appreciated the quality of the presentations of the physicians-in-training of Tenri Hospital and the intimate atmosphere of this small meeting.

\section{ACKNOWLEDGEMENTS}

The meeting was principally supported by the Nara Society for Malignant Lymphoma and co-sponsored by the Nara branch of Kyowa Hakko Kirin Co., Ltd. We would like to thank Professor K. Nakamine (Kansai University of Health Sciences) for contributing to the success of this mini-symposium.

\section{REFERENCES}

1. Dawson PJ. The original illustrations of Hodgkin's disease. CA: A Cancer Journal for Clinicians 1970;20:298-301.

2. Stone MJ. Thomas Hodgkin: medical immortal and uncompromising idealist. Proc (Bayl Univ Med Cent) 2005;18:368-375.

3. Wilks S. Cases of enlargement of the lymphatic glands and spleen, (or, Hodgkin's disease,) with remarks. Guy's Hospital Reports (Third Series) 1865;11:56-67. 


\section{ミーティングレポート “ホジキンリンパ腫 : 症例提示と天理よろづ相談所病院にお ける治療成績”}

大野仁嗣

天理よろづ相談所病院 血液内科

2013 年 2 月 2 日, 奈良ロイヤルホテルにおいて “ホジキンリンパ腫：症例提示と天理よろづ相談所病院における治 療成績” と題するミニシンポジウムが開催された. 本シンポジウムは, 天理よろづ相談所病院で研修中のレジデントに, 自身が担当したホジキンリンパ腫患者の診療を通じて知り得た知識や理解を発表する機会を提供することを目的として企 画されたものであった. 当日は, 奈良県内で血液疾患の診断や治療にかかわっている血液内科医, 放射線科医, 病 理医が多数参加し，熱心なディスカッションが行われた．本レポートでは，まず，この疾患を 180 年前に初めて記載し たThomas Hodgkin 博士のバイオグラフィーを略記した． 次いで，天理よろづ相談所病院レジデント諸君の発表のな かから, 最も重要な知見をいくつか取り上げた.

キーワード: ホジキンリンパ腫，Thomas Hodgkin 博士，天理よろづ相談所病院レジデント 